\title{
Considerations for the design of Human Immunodeficiency Virus (HIV) prevention programs for lesbian and bisexual women
}

Diana M. Palma ${ }^{(a)}$

Linda Teresa Orcasita(b)

\section{Introduction}

In the last decade, the increased percentage of women affected by HIV has encouraged the implementation of several intervention strategies in order to reduce these rates and address its effects. According to the Joint United Nation Program on HIV/AIDS ${ }^{1,2}, 50 \%$ of the people living with HIV are women. Although nearly seven thousand cases of HIV positive lesbian and bisexual women (LB) are estimated in the United States ${ }^{3}$, the global numbers remain invisible in global reports, even when HIV transmission between them has been scientifically proven ${ }^{4,5}$. This is a great weakness in the characterization of the epidemic among this group, particularly in places with a high burden of HIV cases, such as Africa, where it has been demonstrated that women from sexual minorities face particular social and structural susceptibilities related to sexual stigma and violence, which significantly exposes them to HIV6.

Despite the fact that some women voluntarily report their sexual orientation when the HIV diagnosis occurs, many others prefer to remain silent while this unknown figure keeps quietly increasing. Thus, there is an important task of developing intervention guidelines for this population to prevent the growth in figures of women affected by HIV, not only to fulfill a gap in the attention of their particular needs, but also to extinguish the traditional resistance to include them in several programs and policies that have invalidated their existence ${ }^{7,8}$.

This invisibility is the consequence of their traditional absence and exclusion in HIV prevention due to the ignorance of their vulnerability; gender bias regarding normative conceptions towards women that underrepresent LB women at communities and institutional levels; and a heteronormative approach that has delimitated the design of programs by assuming heterosexual identities as a natural norm for women ${ }^{9,10}$. As suggested by Richardson ${ }^{11}$, the non-risk perception of LB women has been built and perpetuated among several social agents over the past couple of decades. As stated by this author, the HIV risk perception toward this community has sociohistorical roots and this fact have reduced the endeavors and resources granted to this population ${ }^{11}$.

In comparison with men, who have been the target of several prevention programs designed according to their sexual orientation and practices $^{7}$, the 
inclusion criteria in HIV prevention programs for women are neutral to their sexual orientations, barely considering lesbian and bisexual practices in their prevention strategies.

In HIV prevention programs for women, multiple social and gender factors that shape their vulnerability have been addressed beyond their sexual practices, including biological, epidemiological, social and cultural components ${ }^{12}$. Aspects such as poverty, inequity, lack of education and gender violence have been related to HIV exposure in women around the world ${ }^{13}$. Therefore, recognizing the fact that gender entails a large spectrum of experiences that include sexual orientation and identity, we face the challenge of including LB women on prevention programs and addressing their particular health care needs due to the intersectionality that occurs among gender, sexual orientation, ethnicity and other social characteristics ${ }^{10}$.

Human rights are universal and protect dignity and freedom, including the right to health. This is not referring exclusively to a proper health care; it also includes receiving accurate information, participating in health care programs, being treated equally and without discrimination. As suggested by Fish and Bewley, the silence and invisibility that has surrounded LB women in the HIV epidemic is a violation of their human rights ${ }^{14}$.

In fact, HIV prevention programs designed for this population are almost nonexistent, but few efforts have been reported in high-income countries ${ }^{7,15,16}$. Although those programs have different perspectives regarding the proper strategies for approaching sexual orientation and sexual practices, they all agree that identity must be a fundamental component of HIV prevention for this population. In those programs, the sexual transmission pathway is prioritized while other ways of transmission, such as drug abuse are not addressed. This is still a challenge for prevention programs oriented towards LB women ${ }^{8}$.

\section{Key topics in HIV prevention for LB women}

Throughout the HIV/AIDS epidemic, sexual practices and health behaviors have been widely addressed by prevention programs. However, specific topics have been approached depending on the characteristics, experiences, and needs of every population.

Due to the low number of interventions reported within this group, it is important to discuss key aspects to have in mind while designing an HIV prevention program for LB women. They must address the ways in which particular individual, social and structural factors configure their particular HIV vulnerability ${ }^{10}$.

Among the 'individual factors', the basic topics in prevention programs are HIV knowledge and safer sex strategies. Particularly in this population a low level of knowledge about HV and STDs have been reported, both in low and high-income countries, showing that the discourses of public preventive messages might not adequate enough to reach this population ${ }^{17-19}$. Likewise, the performance of safer sex strategies, such as condoms or latex barriers, has been found to be hindered by their low-risk perception and knowledge about how to use them ${ }^{20,21}$.

Therefore, programs oriented to this population should emphasize these components because sexual education for LB women is significantly lower in comparison with heterosexual women ${ }^{22}$. This situation may affect the quality of health care and social support, because the information provided by different agents such as family, teachers, peers, health professionals and media, is generally detached from their needs, concerns, sexual practices, and experiences ${ }^{14,23}$.

Beyond providing information about HIV, programs must use strategies to address ethnical, cultural and gender factors of female sexual health. This includes overcoming barriers to talk about sexuality; broadening the definition of sexuality and detaching it from their reproductive function exclusively; preventing gender violence and discrimination; creating communication and negotiation skills and recognizing and engaging in social support networks ${ }^{13,24} 25$.

Other individual risk factors that have been reported for women's sexual health that must be addressed in prevention programs, such as the increased use of alcohol and drugs in comparison with their heterosexual peers ${ }^{26,27}$; and an increased risk of suicidal thoughts and attempts ${ }^{28}$. Likewise, a higher HIV prevalence has been found in high-income countries when comparing LB Intravenous Drug 
Users with heterosexual women ${ }^{27}$, proving that not only sexual transmission needs to be considered in intervention strategies designed for them.

In previous research with women, participants have reported that the programs succeeded due to the inclusion of topics that impacted their mental health, such as their affection and emotions, in addition to their sexual practices and knowledge ${ }^{24}$.

At a 'social level', sexual identity development and its disclosure is an important task for LGBT people and this process exposes them to several stressors such as: seeking individual and social acceptance of their sexual identity; disclosing their sexual orientation to family, friends, work/ study partners; and facing possible reactions of different socialization agents. In this situation, the dampening effect of social support networks is essential ${ }^{29}$. However, the relationship between low social support, perceived family distance, and risky sexual practices has been widely reported in the population ${ }^{30}$. Therefore, addressing feelings and experiences linked to sexual orientation disclosure and family reaction could be necessary for programs oriented to LB women, because these variables are linked to their sexual practices and to the image they have built about themselves.

Authors working with similar populations such as MSM and transgender women, who also go through this process of acceptance, have indicated the relevance of considering the developmental needs and interests according to the age of the participants, as well as providing skills to cope with different reactions and empower them to make healthier choices ${ }^{24,25}$. These could be achieved by using strategies and activities adjusted to cultural, ethnic and gender aspects of the target population. It is suggested to provide spaces in which LB women can express their concerns and experiences about their sexual practices and their identity as women. It would also be pertinent to approach issues related to family and partners and their perspectives on future and maternity because these topics are not commonly discussed in any other social spheres.

Discrimination and violence against the identity of vulnerable populations (MSM and transgender people) have been widely included in HIV prevention ${ }^{31}$. In these interventions, participants appreciated when they are taught how to access existing resources and social networks, as well as discussing the social expectations about love and intimacy ${ }^{32}$. It has also been reported that successful programs are those that have an integral approach to health, because they address specific health needs, social inequalities and discrimination ${ }^{33}$. Considering that these appreciations converge with studies that have demonstrated the need to strengthen social support networks in LB women ${ }^{22}$, these components must be included in programs.

Another component that should be addressed in this population is intimate partner violence (IPV). This concept refers to an abuse within an intimate relationship that can be psychical, sexual or psychological ${ }^{34}$. Studies from high-income countries, such as the United States, have found an alarming rate of IPV in the LGBT population ${ }^{35,36}$. A longitudinal study in LGBT people reported a $45 \%$ incidence of IVP. Especially, they found that the odds of suffering IVP if they were lesbian or bisexual females were $76 \%$ more than in gay men. Another study also found a higher rate of physical and sexual IPV in LB when compared to gay men $^{37}$.

Authors such as Miller et al. ${ }^{35}$ have suggested that the obstacles that have hindered the recognition of IPV in LB women are ingrained in gender norms because programs and policies have been created by focusing on heterosexual women and they have neglected the people outside that category. Thus, poor law enforcement towards same-sex IVP; poor social support; stigma within the judicial system and health care centers; and social and individual perceptions of less severity towards same-sex IVP, have contributed to the low attention and underreporting of this issue ${ }^{34}$.

It is important to mention that, although the association between IVP and HIV exposure has been described in heterosexual women and gay men, because it reduces condom negotiation ${ }^{34,38}$, the link is still understudied in LB women, but it is important to address it in prevention programs due to the mentioned rates. Additionally, greater efforts to characterize IVP in LB women should be made, especially in low-middle income countries, to be able to strengthen existing units for IVP attention from a sexual diversity approach.

On the other hand, 'structural drivers' related to HIV vulnerability for LB women are lower rates of access to healthcare in high and low-income countries. Few studies conducted in the population have 
revealed that LB women feel that health workers do not meet their needs; prefer to hide their sexual orientation in health services out of fear or services are often denied ${ }^{6,16,39}$. This situation may delay the detection of possible irregularities and treatment on time for this population. In order to ensure their human right to health, this structural level in health care systems must be addressed and physicians must be trained about LGBT healthcare needs. This goal implies providing skills for demanding accurate attention and revealing the sexual orientation in health care services, as well as integrating risk reduction with other specific needs of LGBT people, such as empowerment and social concerns, in individual prevention efforts.

Including structural approaches in HIV prevention, addressing underlying risks such as stigma, health care access, discrimination, and violence, may lead to more successful strategies ${ }^{40}$. Recently, the link between human rights violations and HIV vulnerability was confirmed in a sample of LB women in Africa ${ }^{6}$. One relevant issue that maximizes the risk of HIV in LB women is the figures of sexual harassments reported by them. Studies have reported figures from $8 \%$ to $30 \%$ of sexual abuses related to sexual orientation in countries like the United States, Africa and Colombia ${ }^{6,26,41}$. Therefore, in order to safeguard the human rights of LGBT people, as it was established by the United Nations Human Rights Commission ${ }^{42}$, states have the legal obligation to plan and develop actions to mitigate this situation and protect them from sexual violence and discrimination.

This situation shows how important is to include political aspects on HIV prevention for LB women. Previous studies focusing on this group have revealed this need. In the study conducted by McAlister and Neil22, participants reported the urgency of designing programs that merge the individual and political aspect. This means promoting empowering and self-discovering through the activities used. The pertinence of this political approach in HIV prevention programs for LB women was also stated by Morrow ${ }^{7}$, because improving political awareness could also enhance health access and demand of proper attention, participating in policy making, community building, and advocacy.

The previous suggestions illustrate how specific characteristic in regard to gender, sexual orientation, age, ethnic and others configures the vulnerability of the population. This intersectionality, the way in which different identities and individual characteristics converge to shape particular experiences and vulnerabilities ${ }^{10}$, must be addressed in HIV prevention programs for LB women and must be adjusted to the culture in which they are implemented.

Other general aspects that could be considered while designing an HIV prevention program targeting LB women are: (a) Creating a baseline about their knowledge, attitudes, and behaviors due to the scarcity of information about HIV and LB women; (b) including intervention topics based on a human rights and gender perspective; (c) approaching sexuality in all their functions (biological, erotic and communicative); (d) justifying its theoretical and methodological model in regard to previous successful experiences and backgrounds in the community; (e) allowing the discussion of their concerns in a safe place through the activities suggested. Implementing programs with small groups could be useful in this aim, because it allows a major exchange and debate among them; ( $f$ ) training facilitators with an affirmative perspective that allows them to recognize and value the identity and needs of participants; ( $g$ ) including community leaders in the design to ensure the pertinence and adjustment of the strategies used; (h) monitoring and assessing the activities and strategies used in the program to verify their effectiveness, improve them and adjust them according to their characteristics; (j) spreading the intervention experiences in education institutes, health centers and community-based organizations aiming to ensure that the endeavors to protect sexual health become visible to several agents and organizations.

In conclusion, programs oriented to the LB community must address the way in which pleasureseeking, risk perception, identity exploration, lack of knowledge, sexual abuse and drug abuse; create a particular vulnerability that sets this population at risk for HIV and other STDs. They should avoid exclusive biomedical perspectives that ignore the existence of social and structural drivers that may increase this risk ${ }^{10,26}$. Furthermore, given the lack of research about this topic, more studies are needed in low, middle and high-income countries to characterize the mentioned variables in order to create effective and sensible intervention strategies. 


\section{Collaborators}

DM Palma conducted the literate review and wrote the first draft of this paper; LT Orcasita gave feedback and supported the reflections on the contents included in the final version submitted for publication.

\section{References}

1. Joint United Nations Programme on HIV/AIDS. 2012 World AIDS Day Report [Internet]. Geneva: UNAIDS; 2012 [cited 16 Aug 2015]. Available from: http://www.unaids.org/ en/media/unaids/contentassets/documents/epidemiology/2012/gr2012/JC2434 WorldAIDSday_results_en.pdf.

2. Joint United Nations Programme on HIV/AIDS. Global Report: UNAIDS report on the global AIDS epidemic 2013 [Internet]. Geneva: UNAIDS; 2013 [cited 20 Jul 2015]. Available from: http://www.unaids.org/en/media/unaids/contentassets/documents/ epidemiology/2013/gr2013/UNAIDS_Global_Report_2013_en.pdf.

3. Teti $M$, Bowleg L. Shattering the myth of invulnerability: exploring the prevention needs of sexual minority women living with HIV/AIDS. J Gay Lesbian Soc Serv. 2011; 23(1):69-88. doi: 10.1080/10538720.2010.538009.

4. Fethers K, Marks C, Mindel, Estcourt C. Sexually transmitted infections and risk behaviours in woman who have sex with woman. Sex Transm Infect. 2000; 76(5):345-9.

5. Kwakwa HA, Ghobrial MW. Female-to-female transmission of human immunodeficiency virus. Clin Infect Dis. 2003; 3(3):e40-1.

6. Poteat T, Logie C, Adams D, Mothopeng T, Lebona J, Letsie P, et al. Stigma, sexual health, and human rights among women who have sex with women in Lesotho. Reprod Health Matters. 2015; 23(46):107-16. doi: 10.1016/j.rhm.2015.11.020.

7. Morrow KM. Culture-specific HIV/STD prevention programming for lesbian and bisexual women [dissertation] Michigan: Western Michigan University; 1996.

8. Palma DM, Munévar J, Orcasita LT. Percepción de riesgo frente al VIH/Sida en mujeres homosexuales: retos y desafíos actuales desde la investigación. In: Soriano E, González A, Cala V, editors. Retos actuales de educación y salud. Almería: Editorial Universidad de Almería; 2014. v. 2.

9. Joint United Nations Programe on HIV/AIDS. Woman who have sex with woman, in all their diversity: putting their needs and right on the HIV agenda. Community innovation: achieving sexual and reproductive health and rights for women and girls through the HIV response [Internet]. Geneva: UNAIDS; 2011 [cited 13 Mar 2013]. Available from: http://www.unaids.org/en/media/unaids/contentassets/documents/ document/2011/07/20110719_Community\%20innovation.pdf.

10. Logie C. (Where) do queer women belong? Theorizing intersectional and compulsory heterosexism in HIV research. Crit Public Health. 2015; 25(5):527-38. doi: 10.1080/09581596.2014.938612.

11. Richardson D. The social construction of immunity: HIV risk perception and prevention among lesbians and bisexual women. Cult Health Sex. 2000; 2(1):33-49.

12. Herrera C, Campero L. La vulnerabilidad e invisibilidad de las mujeres ante el VIH/SIDA: constantes y cambios en el tema. Salud Publica Méx. 2002; 44(6):554-64.

13. Dunbar M, Dufour M, Lambdin B, Mudekunye- Mahaka I, Nhamo D, Padian N. The SHAZ! Project: results from a pilot randomized trial of a structural intervention to prevent HIV among adolescent women in Zimbabwe. PLOS One. 2014; 9(11):e113621. doi:10.1371/journal.pone.0113621. 
14. Fish J, Bewley S. Using human rights-based approaches to conceptualise lesbian and bisexual women's health inequalities. Health Soc Care Community. 2010; 18(4):355-62. doi: 10.1111/j.1365-2524.2009.00902.x.

15. Stevens P. HIV prevention education for lesbian and bisexual women: a cultural analysis of a community intervention. Soc Sci Med. 1994; 39(11):1565-78.

16. Logie C, Lacombe-Duncan A, Weaver J, Navia D, Este D. A pilot study of a groupbased HIV and STI prevention intervention for lesbian, bisexual, queer, and other women who have sex with women in Canada. AIDS Patient Care STDS. 2015; 29(6):321-8. doi: 10.1089/apc.2014.0355.

17. Mora C, Monteiro S. Vulnerability to STIS/HIV: sociability and the life trajectories of young women who have sex with woman in Rio de Janeiro. Cult Health Sex. 2010; 2(1):115-24. doi: 10.1080/13691050903180471.

18. Power J, McNair R, Carr S. Absent sexual scripts: lesbian and bisexual women's knowledge, attitudes and action regarding safer sex and sexual health information. Cult Health Sex. 2009; 11(1):67-81. doi: 10.1080/13691050802541674.

19. Profamilia, Grupo de Estudios de Género, Sexualidad y Salud en América Latina, Centro Latinoameticano de Sexualidad y Derechos Humanos. Encuesta LGBT: sexualidad y derechos. Participantes de la marcha de la ciudadanía LGBT de Bogotá, 2007 [Internet]. Bogotá: Profamilia; 2007 [cited 20 Jul 2014). Available from: http://www.bdigital.unal. edu.co/47154/1/9789587192384.pdf.

20. Muzny C, Harbison C, Pembleton E, Hook E, Austin E. Misperceptions regarding protective barrier method use for safer sex among African-American women who have sex with women. Sex Health. 2013; 10(2):138-41. doi: 10.1071/SH12106.

21. Rowen T, Breyer B, Lin T, Li C, Robertson P, Shindel A. Use of barrier protection for sexual activity among women who have sex with women. Int J Gynaecol. 2013; 120(1):42-5. doi: 10.1016/j.ijgo.2012.08.011.

22. McAlister S, Neill G. "The L Pack": addressing the sexual health needs of young lesbians. Child Care Pract. 2009; 15(3):209-26.

23. Mollon L. The forgotten minorities: health disparities of the lesbian, gay, bisexual, and transgendered communities. J Health Care Poor Underserved. 2012; 23(1):1-6. doi: 10.1353/hpu.2012.0009.

24. Brothers J, Harper G, Fernandez I, Hosek S, The adolescent trials network for HIV/ AIDS interventions. EVOLUTION-Taking charge and growing stronger: the design, acceptability, and feasibility of a secondary prevention empowerment intervention for young women living with HIV. AIDS Patient Care STDS. 2014; 28(1):33-42.

25. Pryce J, Silverthorn N, Sanchez B, DuBois D. GirlPOWER! Strengthening mentoring relationships through a structured, gender-specific program. New Dir Youth Dev. 2010; 126:89-105. doi: 10.1002/yd.351.

26. Lindley L, Walsemann K. Invisible and at risk: STDs among young adult sexual minority women in the United States. Perspect Sex Reprod. 2013; 45(2):66-73. doi: $10.1363 / 4506613$.

27. Ompad D, Friedman S, Hwahng S, Nandi V, Fuller C, Vlahov D. HIV risk behaviors among young drug using women who have sex with women (WSWs) in New York City. Subst Use Misuse. 2011; 46(2-3):274-84. doi: 10.3109/10826084.2011.523284. 
28. Mustanski B, Liu R. A longitudinal study of predictors of suicide attempts among lesbian, gay, bisexual, and transgender youth. Arch Sex Behav. 2013; 42(3):437-48. doi: 10.1007/s10508-012-0013-9.

29. Jiménez $M$, Borerro N, Nazario J. Adolescentes gays y lesbianas en Puerto Rico: procesos, efectos y estrategias. Rev Puertorriqueña Psicol. 2011; 22:147-73.

30. Bregman HR, Malik NM, Page MJL, Makynen E, Lindahl KM. Identity profiles in lesbian, gay, and bisexual youth: the role of family influences. J Youth Adolesc. 2013; 42(3):417-30. doi10.1007/s10964-012-9798-z.

31. Garofalo R, Johnson A, Kuhns L, Cotten C, Joseph H, Margolis A. Life skills: evaluation of a theory-driven behavioral HIV prevention intervention for young transgender women. J Urban Health. 2012; 89(3):419-31. doi:10.1007/s11524-011-9638-6.

32. Rhodes S, Alonzo J, Mann L, Downs M, Simán FM, Andrade M, et al. Novel approaches to HIV prevention and sexual health promotion among Guatemalan gay and bisexual men, MSM, and transgender persons. AIDS Educ Prev. 2014; 24(4):345-61.

33. Gelaude D, Sovine M, Swayzer R, Herbst J. HIV prevention programs delivered by community-based organizations to young transgender persons of color: lessons learned to improve future program implementation. Int J Transgend. 2013; 14(3):127-39. doi:10.108 $0 / 15532739.2013 .824846$

34. Mitchell J, Wight $M$, Van Heerden A, Rochat T. Intimate partner violence, HIV, and mental health: a triple epidemic of global proportions. Int Rev Psychiatry. 2016; 28(5):452-63. doi: 10.1080/09540261.2016.1217829.

35. Miller B, Irvin J. Invisible scars: comparing the mental health of LGB and heterosexual intimate partner violence survivors. J Homosex. 2016; 1-16. doi: 10.1080/00918369.2016.1242334.

36. Whitton S, Newcomb ME, Messinger AM, Byck G, Mustanski B. A longitudinal study of IPV victimization among sexual minority youth. J Interpers Violence. 2016; 1-31. doi: $10.1177 / 0886260516646093$.

37. Martin-Storey A. Prevalence of dating violence among sexual minority youth: variation across gender, sexual minority identity and gender of sexual partners. J Youth Adolesc. 2014; 44(1):211-24. doi:10.1007/s10964-013-0089-0.

38. Stephenson R, Freeland R, Finneran C. Intimate partner violence and condom negotiation efficacy among gay and bisexual men in Atlanta. Sex Health. 2016; 13:36672. doi: $10.1071 / \mathrm{SH} 15212$.

39. Colombia Diversa. Provisión de servicios afirmativos de salud para personas LGTB (Lesbianas, Gays, Bisexuales y Transgeneristas). Bogotá: Colombia Diversa; 2010.

40. Gumpta R, Parkhurst J, Ogden J, Aggleton P, Mahal A. Structural approaches to HIV prevention. Lancet. 2008; 372(9649):764-75. doi: 10.1016/S0140-6736(08)60887-9.

41. Palma DM, Orcasita LT. La solución es la tijera: programa de salud sexual para mujeres lesbianas y bisexuales. Psic Teor Pesq. Forthcoming 2018.

42. United Nations Human Rights Commission. Born free and equal: sexual orientation and gender identity in international human rights law [Internet]. New York: United Nations; 2012 [cited 12 Apr 2016]. Available from: http://www.ohchr.org/Documents/ Publications/BornFreeAndEqualLowRes.pdf. 
Several strategies and guidelines for HIV prevention in different population groups have been established throughout the epidemic. However, there is an urgent need to include lesbian and bisexual women (LB women) in prevention programs and address their particular health care needs. This paper discusses key aspects that must be considered in the design of HIV prevention programs oriented toward this specific population. Due to the lack of research assessing prevention strategies for LB women, these reflections emerged by reviewing literature in similar groups and by the direct work of the authors within this group. Their inclusion in the HIV prevention agenda is essential to safeguard their right to health care in terms of receiving accurate information about sexuality and health, participating in health care programs and being treated equally and without any discrimination.

Keywords: HIV. Sex education. Prevention. Lesbian women.

\section{Considerações para a elaboração de programas de prevenção do Vírus da Imunodeficiência Humana (VIH) para as mulheres lésbicas e bissexuais}

Várias estratégias e diretrizes para a prevenção da epidemia do HIV foram estabelecidas para diferentes populações. No entanto, há uma necessidade de incluir as mulheres lésbicas e bissexuais (mulheres LB) em programas de prevenção e resposta às suas necessidades de saúde particulares. Este artigo discute os principais aspectos que devem ser considerados na elaboração de programas de prevenção do VIH voltadas para essa população específica. Devido à falta de pesquisas avaliando estratégias de prevenção para as mulheres LB, essas reflexões emergiram através da revisão da literatura em grupos similares e pelo trabalho direto dos autores nesse grupo. A sua inclusão na agenda da prevenção do VIH é essencial para salvaguardar o seu direito a cuidados de saúde em termos de receber informações precisas sobre sexualidade e saúde, participe de programas de saúde e ser tratados com igualdade e sem discriminação.

Palavras-chave: VIH. Educação sexual. Prevenção. Mulheres lésbicas.

\section{Consideraciones para la elaboración de programas de prevención del Virus de la Inmunodeficiencia (VIH) para las mujeres lesbianas y bisexuales}

Se establecieron diversas estrategias y directrices para la prevención de la epidemia de VIH para diferentes poblaciones. Sin embargo, hay una necesidad de incluir a las mujeres lesbianas y bisexuales (mujeres LB) en programas de prevención y respuesta a sus necesidades particulares de salud. Este artículo discute los principales aspectos que deben considerarse en la elaboración de programas de prevención del VIH, enfocados para esa población específica. Debido a la falta de investigación que evalúe estrategias de prevención para las mujeres LB, esas reflexiones surgieron por medio de la revisión de la literatura en grupos similares y por el trabajo directo de los autores en ese grupo. Su inclusión en la agenda de la prevención del VIH es esencial para salvaguardar su derecho a cuidados de salud en lo que se refiere a recibir informaciones precisas sobre sexualidad y salud, participación en programas de salud y tratamiento con igualdad y sin discriminación.

Palabras clave: VIH. Educación sexual. Prevención. Homosexualidad femenina. 